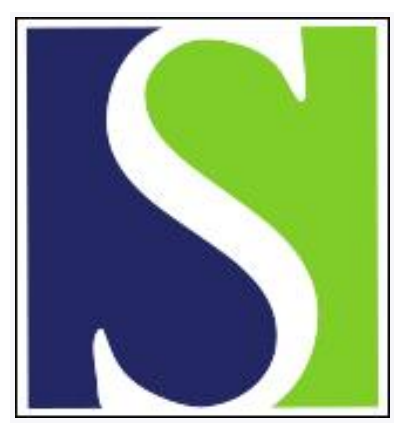

Scand J Work Environ Health 1984;10(5):325-326

https://doi.org/10.5271/sjweh.2321

Issue date: Oct 1984

Confounding by variable smoking habits in different occupational groups.

by Asp S

This article in PubMed: www.ncbi.nlm.nih.gov/pubmed/6523098

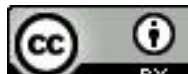

This work is licensed under a Creative Commons Attribution 4.0 International License 


\title{
Confounding by variable smoking habits in different occupational groups
}

\author{
by Sisko Asp, MSocSc${ }^{1}$
}

\begin{abstract}
ASP A. Confounding in occupational lung cancer studies: What is the variability in smoking habits across different occupations? Scand J Work Environ Health 10 (1984) 325-326. Smoking habits of different occupational groups were studied in a sample of persons who participated in health screening examinations carried out by the mobile clinic of the Institute of Occupational Health (Helsinki, Finland). The sample consisted of 1990 men and 1044 women. The smoking habits of the study population as a whole conformed with those of the entire Finnish population. Distinct differences in smoking habits were found, however, in different occupational groups. The effect of smoking habits on tentative rate ratios of lung cancer in occupational groups were estimated with a procedure presented by Olav Axelson. The groups were selected from extreme ends of the smoking habit variable. Extreme estimates were taken to maximize the confounding effect of smoking. When occupational groups were contrasted with the general population, the confounding effect was found to be smaller than usually believed.
\end{abstract}

Key terms: occupational groups, smoking.

Smoking habits may confound the results of studies on lung cancer mortality and morbidity in various occupational groups. Information on smoking habits is particularly hard to obtain in studies based on register data. Methods of control for smoking in occupational cohort mortality studies have been discussed recently in this journal (6). Therefore I would like to present some data on the variability of smoking habits among various occupational groups and to discuss their confounding impact on tentative lung cancer mortality data.

The material is a sample of persons who participated in health screening examinations carried out by the mobile clinic of the Institute of Occupational Health (Helsinki, Finland) between 1970 and 1975. In all, 1990 men and 1044 women were included. Information on smoking was collected by questionnaire. The subjects were asked whether they were currently smokers and, on an average, how many cigarettes they smoked daily. Persons who had stopped smoking were asked at what age they stopped and the reason for quitting.

The smoking habits of the study population conformed with the smoking habits of the entire Finnish population $(1,3,4,5)$. The men smoked more than the women, and young persons smoked more than older persons. Women in urbanized areas smoked more than women in rural areas, but the men's

\footnotetext{
1 Department of Epidemiology and Biometry, Institute of Occupational Health, Helsinki, Finland.

Reprint requests to: Ms S Asp, Institute of Occupational Health, Haartmaninkatu 1, SF-00290 Helsinki, Finland.
}

smoking habits did not vary according to geographic district.

As can be seen from table 1, distinct differences in smoking were found for different male occupational groups. The percentage of smokers was the lowest for civil servants, business executives, and office workers and the highest for heavy occupations such as mining, basic metal industry, and construction work. These findings concern both the percentage of smokers in the groups and the number cigarettes smoked daily. As the women of the sample fell into only a few occupational categories, no clear conclusions about their smoking habits across occupational groups could be drawn. The responses indicated however that female industrial workers smoke more than female office workers.

When the procedure presented by Axelson (2) and discussed in a later article in this journal (6) is applied to the present data, the effect of smoking habits on tentative rate ratios of lung cancer in occupational groups can be estimated (table 2). The occupational groups shown in table 2 were selected from the extreme ends of the smoking habit variable. The calculations were performed with the data of the male workers only. Smoking habits were divided into the categories of nonsmokers, exsmokers, and smokers, and the proportions in each occupational group were standardized to the age distribution of the total material. The rate ratios so obtained show the confounding effect of the real smoking differences in a situation where it is assumed that the unconfounded rate ratios are the same, ie, 1.0, for all the occupational groups. 
Table 1. Percentage of male nonsmokers, exsmokers, and smokers in the various occupational groups.

\begin{tabular}{|c|c|c|c|c|}
\hline \multirow[b]{2}{*}{$\begin{array}{l}\text { Occupational } \\
\text { group }\end{array}$} & \multirow[b]{2}{*}{ Number } & \multicolumn{3}{|c|}{ Percentage of group } \\
\hline & & $\begin{array}{l}\text { Non- } \\
\text { smok- } \\
\text { ers }\end{array}$ & $\begin{array}{l}\text { Ex- } \\
\text { smok- } \\
\text { ers }\end{array}$ & $\begin{array}{l}\text { Smok } \\
\text { ers }\end{array}$ \\
\hline $\begin{array}{l}\text { Scientific and engineering } \\
\text { personnel }\end{array}$ & 53 & 27 & 37 & 36 \\
\hline Technical assistants & 112 & 21 & 40 & 39 \\
\hline Other professionals & 23 & 13 & 20 & 67 \\
\hline Civil servants & 47 & 41 & 37 & 22 \\
\hline Business executives & 69 & 30 & 40 & 30 \\
\hline Office workers & 41 & 21 & 45 & 34 \\
\hline Custom-house personnel & 114 & 27 & 30 & 43 \\
\hline Officials in post offices & 32 & 32 & 32 & 36 \\
\hline Mail carriers & 108 & 22 & 25 & 53 \\
\hline $\begin{array}{l}\text { Miners and workers in the } \\
\text { basic metal industry }\end{array}$ & 79 & 20 & 17 & 63 \\
\hline Mechanics & 104 & 30 & 28 & 42 \\
\hline $\begin{array}{l}\text { Workers in the metal product } \\
\text { industry }\end{array}$ & 165 & 22 & 26 & 52 \\
\hline Carpenters and painters & 81 & 27 & 23 & 50 \\
\hline Construction workers & 32 & 10 & 16 & 74 \\
\hline $\begin{array}{l}\text { Electricians and workers } \\
\text { in power stations }\end{array}$ & 197 & 24 & 32 & 44 \\
\hline $\begin{array}{l}\text { Industrial workers } \\
\text { Chemical industry } \\
\text { Rubber and plastic }\end{array}$ & 164 & 28 & 30 & 42 \\
\hline $\begin{array}{l}\text { industries } \\
\text { Printing industry } \\
\text { Foodstuff industry } \\
\text { Other industries }\end{array}$ & $\begin{array}{l}39 \\
52 \\
41 \\
50\end{array}$ & $\begin{array}{l}18 \\
27 \\
17 \\
14\end{array}$ & $\begin{array}{l}26 \\
32 \\
44 \\
19\end{array}$ & $\begin{array}{l}56 \\
41 \\
39 \\
67\end{array}$ \\
\hline $\begin{array}{l}\text { Operators and repairmen } \\
\text { of stationary machines }\end{array}$ & 94 & 25 & 25 & 50 \\
\hline $\begin{array}{l}\text { Packers, loaders and } \\
\text { depot workers }\end{array}$ & 65 & 13 & 22 & 65 \\
\hline $\begin{array}{l}\text { Operators of mobile } \\
\text { machines }\end{array}$ & 47 & 7 & 25 & 68 \\
\hline Truck drivers & 44 & 22 & 25 & 53 \\
\hline $\begin{array}{l}\text { Farmers and animal } \\
\text { tenders }\end{array}$ & 47 & 49 & 11 & 40 \\
\hline $\begin{array}{l}\text { Other miscellaneous } \\
\text { occupations }\end{array}$ & 90 & 26 & 27 & 47 \\
\hline Total & 1990 & 24 & 28 & 48 \\
\hline
\end{tabular}

The rate ratios applied in the example are extreme. For example, it has often been stated that the lung cancer risk for exsmokers approaches that for nonsmokers. Extreme estimates were taken to maximize the confounding effect of smoking. This exercise showed that, when occupational groups are contrasted with the general population, the confounding effect in occupational lung cancer studies is smaller than usually believed. In this study the extreme was an effect of 0.31 upon the rate ratio for construction workers, when compared with an approximation of the rate ratio of the general population.

\section{References}

1. Aromaa A, Reunanen A. Savukkeiden polton yleisyyden muutokset - vuosien 1966 ja 1972 tietojen vertailuja [Changes in cigarette smoking in Finland, comparisons of data from 1966 and 1972 ]. Suom Lääkäril 30 (1975) 487-493.
Table 2. Estimated tentative rate ratios of lung cancer in relation to the percentage of nonsmokers, exsmokers, and smokers in various occupational groups.

\begin{tabular}{|c|c|c|c|c|}
\hline \multirow[b]{2}{*}{$\begin{array}{l}\text { Occupational } \\
\text { group }\end{array}$} & \multicolumn{3}{|c|}{ Percentage of group } & \multirow[b]{2}{*}{$\begin{array}{l}\text { Esti- } \\
\text { mated } \\
\text { rate } \\
\text { ratio }\end{array}$} \\
\hline & $\begin{array}{l}\text { Non- } \\
\text { smok- } \\
\text { ers } \\
(R=1)\end{array}$ & $\begin{array}{c}\text { Ex- } \\
\text { smok- } \\
\text { ers } \\
(R=10)\end{array}$ & $\begin{array}{c}\text { Smok- } \\
\text { ers } \\
(R=20)\end{array}$ & \\
\hline
\end{tabular}

Least proportion of smokers

Civil servants

Business executives

Scientific and en-

$\begin{array}{lllll}\text { gineering personnel } & 27 & 37 & 36 & 0.88\end{array}$

\begin{tabular}{|c|c|c|}
\hline Total study population ${ }^{b}$ & 24 & 28 \\
\hline
\end{tabular}

Greatest proportion of smokers

Miners and workers

in the basic metal

industry

Packers, loaders and

depot workers

Operators of mobile

machines

Construction workers

$\begin{array}{llll}41 & 37 & 22 & 0.67\end{array}$

$\begin{array}{llll}30 & 40 & 30 & 0.81\end{array}$
were calculated with the following procedure: If $I=$ total incidence, $l_{0}=$ incidence among nonsmokers, $I_{S}=$ incidence caused by smoking, $P_{S}=$ proportion of smokers or exsmokers in the material, and $\mathrm{A}=$ assumed effect of smoking expressed as a risk ratio, then

$$
1=I_{S} P_{S}+I_{0}\left(1-P_{S}\right) \text {, }
$$

in which $I_{S} P_{S}$ can be expressed as $\mathrm{RI}_{0} P_{S}$. There are two smoking categories in the example; thus the model is expanded to

$$
\begin{aligned}
& I=R_{1} I_{0} P_{S 1}+R_{2} I_{0} P_{S 2}+I_{0}\left(1-P_{S 1}-P_{S 2}\right) \\
& I_{0}=I /\left[R_{1} P_{S 1}+R_{2} P_{S 2}+\left(1-P_{S 1}-P_{S 2}\right)\right] .
\end{aligned}
$$

$\mathrm{I}_{0}$ of the whole material is divided by the $\mathrm{I}_{0}$ of each occupational group.

b Includes all groups listed in table 1.

2. Axelson $O$. Aspects on confounding in occupational health epidemiology. Scand J Work Environ Health 4 (1978) 85-89. (Letter to the Editor).

3. Rimpelä M. Aikuisväestön tupakointitapojen muutosten seuranta [A follow-up of changes in cigarette smoking among the adult Finnish population]. Sosiaalilääketieteen Aikakausl 15 (1978) 112-123.

4. Rimpelä M. Aikuisväestön tupakointitavat Suomessa 1950-1970-luvuilla [Smoking habits of the adult Finnish population in 1950 to 1970]. Tampereen yliopiston kansanterveystieteen laitos, Tampere 1978, pp 49-52. (Kansanterveystieteen julkaisuja M 40/78).

5. Rimpelä M, Sievers K, Leppo K, Koskelainen O. Aikuisväestömme tupakointitavat ja tupakoinnin aloittamisikä [Smoking habits among the Finnish adult population and the age when smoking was started]. Suom Lääkäril 29 (1974) 2340-2348.

6. Steenland K, Beaumont J, Halperin W. Methods of control for smoking in occupational cohort mortality studies. Scand J Work Environ Health 10 (1984) 143-149.

Received for publication: 30 August 1984 